\title{
FAKTOR YANG MEMPENGARUHI DALAM PENGAMBILAN KEPUTUSAN KLINIS KEPERAWATAN
}

\author{
Natalia Cristianti P Marbun
}

\author{
Email : christiantinatalia72@gmail.com
}

\section{LATAR BELAKANG}

Keperawatan adalah suatu bentuk pelayanan profesional yang merupakan bagian integral dari pelayanan kesehatan berdasarkan ilmu dan kiat keperawatan berbentuk pelayanan biologis, psikologis, sosiologis dan spiritual yang komprehensif/holistik yang ditujukkan kepada individu, keluarga dan masyarakat baik dalam keadaan sehat atau sakit yang mencakup seluruh proses kehidupan manusia yang mengacu pada standar profesional keperawatan dan menggunakan etika keperawatan sebagai tuntutan utama.

Perawat sebagai salah satu profesi baik dari segi jumlah maupun segi kontak dengan pasien memiliki waktu yang lebih lama dibandingkan dengan profesi lain, maka perannya dalam meningkatkan kualitas pelayanan khususnya dalam bidang keperawatan sangat menentukan. Standard kinerja perawat dapat dilakukan dengan menilai berbagai hal, antara lain kecepatan dalam bekerja, tingkat kemandirian, perilaku selama bekerja, kehadiran/pemanfaatan waktu, hubungan dengan staf lain, ketrampilan dalam bekerja, pengetahuan yang dimiliki, keabsahan pekerjaan yang dilakukan. Perawat sebagai ujung tombak dalam pelayanan di rumah sakit, mempunyai tugas memberikan asuhan keperawatan antara lain mengkaji kebutuhan pasien, merencanakan tindakan keperawatan, melaksanakan rencana tindakan, mengevaluasi hasil asuhan keperawatan, mendokumentasikan asuhan keperawatan dan berperan serta dalam melakukan penyuluhan,terkhusus dalam pengambilan keputusan klinis.

Keputusan klinis adalah suatu proses yang meliputi diagnosis klinis, penilaian dan keputusan tentang apa yang harus dilakukan (Ennis 1996). Proses pengambilan keputusan dalam praktik klinik keperawatan dipahami sebagai serangkaian keputusan yang dibuat oleh perawat dalam interaksinya dengan pasien mengenai jenis pengamatan yang akan dilakukan dalam situasi yang 
di alami klien (pengkajian keperawatan), perumusan diagnosa keperawatan, rencana tindakan keperawatan yang harus diambil, tindakan keperawatan yang akan diambil serta evaluasi

Membuat keputusan merupakan bagian dari kehidupan kita sehari-hari baik secara individu ataupun secara kelompok, terutama dalam suatu organisasi. Pengambilan keputusan mempunyai arti penting bagi maju atau mundurnya suatu organisasi. Pengambilan keputusan yang tepat akan menghasilkan suatu perubahan terhadap organisasi ke arah yang lebih baik, namun sebaliknya pengambilan keputusan yang salah akan berdampak buruk pada roda organisasi dan administrasinya.

Setelah dipahami pengertian keputusan, selanjutnya dikutipkan pendapat para ahli mengenai pengertian pengambilan keputusan. Menurut Steiner pengambilan keputusan didefinisikan sebagai suatu proses manusiawi yang didasari dan mencakup baik fenomena individu maupun sosial, didasarkan pada premis nilai dan fakta, menyimpulkan sebuah pilihan dari antar alternatif dengan maksud bergerak menuju suatu situasi yang diinginkan. Pengertian ini menunjukkan bahwa pengambilan keputusan merupakan suatu proses pemilihan alternatif terbaik dari beberapa alternatif secara sistematis untuk ditindak lanjuti (digunakan) sebagai suatu cara pemecahan masalah

\section{METODE}

Metode yang digunakan dalam kajian Jurnal Strategi Pencegahan dan Pengendalian Dalam Upaya Pemutusan Rantai Infeksi Di Rumah Sakit ini menggunakan metode pengumpulan data tersearch dengan menggunakan literature review berdasarkan teks buku,buku referensi,jurnal (10 tahun terakhir),dan juga dibandingkan dengan jurnal yang berhubungan dengan topik materi dengan menganalisis dan membaca setiap sumber literature berkenaan dengan topik materi yang sedang dibahas untuk mendapatkan berbagai informasi yang lengkap dan akurat dengan cara menyimpulkannya dari literature review yang ada 


\section{HASIL}

Perawat merupakan tenaga profesional yang bertanggung jawab dalam memberikan proses keperawatan kepada klien. Berdasarkan hal tersebut perawat harus mampu mengambil keputusan klinis sebagai upaya membantu pasien dalam memecahkan masalah dan menemukan jalan keluar dari seap masalah keperawatan yang dialami pasien. Perawat selalu dihadapkan dengan berbagai masalah klinis dalam memberikan perawatan terhadap pasien. Perawat yang profesional tentu saja akan mampu mengambil keputusan klinis agar masalah pasien dapat diatasi dengan cepat dan tepat. Kurangnya kemampuan perawat dalam mengambil keputusan dalam situasi yang krisis tentu saja akan membahayakan pasien dan menimbulkan kerugian bagi pasien, diantaranya pasien akan terlambat untuk mendapatkan bantuan hidup, kondisi pasien akan semakin memburuk dan akibat yang paling fatal.

Ada lima hal yang perlu diperhatikan dalam pengambilan keputusan :

1. Dalam proses pengambilan keputusan tidak terjadi secara kebetulan.

2. Pengambilan keputusan tidak dilakukan secara sembrono tapi harus berdasarkan pada sistematika tertentu :

a. Tersedianya sumber-sumber untuk melaksanakan keputusan yang akan diambil.

b. Kualifikasi tenaga kerja yang tersedia

c. Falsafah yang dianut organisasi.

d. Situasi lingkungan internal dan eksternal yang akan mempengaruhi administrasi dan manajemen di dalam organisasi.

3. Masalah harus diketahui dengan jelas.

4. Pemecahan masalah harus didasarkan pada fakta-fakta yang terkumpul dengan sistematis.

5. Keputusan yang baik adalah keputusan yang telah dipilih dari berbagai alternatif yang telah dianalisa secara matang.

Apabila pengambilan keputusan tidak didasarkan pada kelima hal diatas, akan menimbulkan berbagai masalah :

a. Tidak tepatnya keputusan.

b. Tidak terlaksananya keputusan karena tidak sesuai dengan kemampuan organisasi baik dari segi manusia, uang maupun material. 
c. Ketidakmampuan pelaksana untuk bekerja karena tidak ada sinkronisasi antara kepentingan organisasi dengan orang-orang di dalam organisasi tersebut.

d. Timbulnya penolakan terhadap keputusan.

\section{PEMBAHASAN}

Keputusan (decision) secara harfiah berarti pilihan (choice). Pilihan yang dimaksud di sini adalah pilihan dari dua atau lebih kemungkinan, atau dapat dikatakan pula sebagai keputusan dicapai setelah dilakukan pertimbangan dengan memilih satu kemungkinan pilihan. Seperti yang diungkapkan oleh Gito Sudarmo, bahwa keputusan terkait dengan ketetapan atau penentuan suatu pilihan yang diinginkan.Definisi di atas mengandung pengertian, dalam keputusan yaitu: (1) ada pilihan atas dasar logika atau pertimbangan

(2) ada beberapa alternatif yang harus dipilih salah satu yang terbaik; dan

(3) ada tujuan yang ingin dicapai dan keputusan itu makin mendekatkan pada tujuan tersebut.

Perawat merupakan unsur vital dalam sebuah Rumah Sakit karena perawat merupakan penjalin kontak pertama dan terlama dengan pasien khususnya pasien rawat inap, dengan tugas utama perawat adalah memberikan asuhan keperawatan dari pengkajian, penegakan diagnose keperawatan, intervensi, implementasi sampai dengan evaluasi (Potter \& Perry, 2009). Perawat juga sebagai seorang praktisi yang berpendidikan diharapkan mempunyai kemampuan intelektual untuk menggunakan pemikiran rasional dan refektif saat perawat mempertimbangkan pengamatan dan informasi tentang kondisi masing-masing pasien. Sepanjang komponen dari proses keperawatan, perawat menggunakan sikap dan kemampuan berfikir kritis untuk menentukan relevansi, makna dan iterrelasi data pasien serta untuk memilih dan menetapkan asuhan keperawatan yang sesuai (Cristensen \& Kenney, 2009)

Dalam pengambilan keputusan yang tepat tentunya harus didasari dengan kemampuan seorang perawat dalam berfikir secara kritis. Perawat harus mampu mengidentifikasi masalah pasien dan memilih solusi intervensi yang tepat, karena perawat akan menghadapi bermacam-macam situasi klinis yang berhubungan dengan pasien dimana hal ini tak lepas dari kemampuan perawat dalam 
berfikir krittis, karena dengan berfikir secara kritis perawat dapat mengambil keputusan secara sistematis dan tepat dalam setiap tahapan asuhan keperawatan yang dilakukan.

Banyak faktor yang berpengaruh kepada individu dan kelompok dalam pengambilan keputusan, antara lain:

\section{a. Faktor Internal}

Faktor internal dari diri manajer sangat mempengaruhi proses pengambilan keputusan. Faktor internal tersebut meliputi: keadaan emosional dan fisik, personal karakteristik, kultural, sosial, latar belakang filosofi, pengalaman masa lalu, minat, pengetahuan dan sikap pengambilan keputusan yang dimiliki.

\section{b. Faktor Eksternal}

Faktor eksternal termasuk kondisi dan lingkungan waktu. Suatu nilai yang berpengaruh pada semua aspek dalam pengambilan keputusan adalah pernyataan masalah, bagaimana evaluasi itu dapat dilaksanakan. Nilai ditentukan oleh salah satu kultural, sosial, latar belakang, filosofi, sosial dan kultural.

Pengambilan keputusan klinik berhubungan dengan beberapa faktor diantaranya adalah:

Usia, pendidikan serikat yang dimiliki perawat, lama kerja di unit dan unit tempat perawat bekerja. Usia merupakan indikator seseorang dalam mengambil keputusan klinik. Semakin bertambahnya umur seseorang maka akan membuat seseorang tersebut semakin bertanggung jawab dan berpengalaman. Selain usia faktor pendidikan juga berperan dalam hal pengambilan keputusan. Survey peneliti ditemukan bahwa masih banyak perawat yang berlatar belakang pendidikan DIII Keperawatan. Data ini menunjukkan bahwa pendidikan yang nggi atau rendah tentu akan berpengaruh bagi seseorang untuk mengambil keputusan. Faktor serfikat yang dimiliki oleh perawat juga seharusnya memiliki hubungan dalam hal perawat mengambil keputusan. Serfikat yang dimiliki perawat sebagai kompetensi yang dimilki perawat dak ternilai harganya, karena kompetensi ini akan mendukung perawat dalam mengambil keputusan independen dalam lingkungan perawatan kris. Kompetensi yang diharapkan dapat berupa serfikasi ngkat lanjut seper advanced cardiac life supports, serfikat klinik ngkat nasional dan keikutsertaan dalam suatu unit medis atau organisasi lain yang sejenis. Faktor lama kerja perawat di unit dan unit tempat perawat bekerja akan mempengaruhi kemampuan dalam membuat 
keputusan. Hal ini tentu saja akan membuat perawat sudah terampil dan terbiasa dengan mengambil keputusan karena pengalaman sebelumnya pada sebuah kasus akan membantu ngkat keberhasilan dari situasi klinis serupa dimasa yang datang.

Pengambilan keputusan sangat penting keberadaannya dalam asuhan maupun dalam manajemen keperawatan. Pengambilan keputusan merupakan suatu proses yang mencakup semua penilaian kegiatan yang diperlukan guna membuktikan dan meperlihatkan pilihan terbaik dalam menyelesaiakan suatu masalah tertentu. setiap keputusan adalah akibat dari sebuah proses dinamis yang dipengaruhi oleh banyak kekuatan, pengambilan keputusana bukan merupakan prosedur yang tetap akan tetapi sebuah proses yang beruntun. pengambilan keputusan adalah proses yang melibatkan pendekatan sistemik yang harus diadaptasikan dengan lingkungan.

Ketepatan pengambilan keputusan akan di pengaruhi oleh kompentisi perawat, kemampuan berkomunikasi, lingkungan serta budaya. Penting bagi perawat untuk selalu meningkatkan kapasitas dirinya dalam pemberian asuhan keperawatan hal ini akan meningkatkan kepercayaan masyarakat terhadap perawat yang selanjutnya akan meningkatkan profesionalisme perawat. Hal ini bisa digunakan sebagai acuan dalam melakukan hubungan interdisiplin.

Cooke \& Slack (1991) menjelaskan 9 tahap yang dilalui individu dalam mengambil keputusan yaitu:

a. Observasi. Individu memperhatikan bahwa ada sesuatu yang keliru atau kurang sesuai, sesuatu yang merupa- kan kesempatan untuk memutuskan sedang terjadi pada lingkungannya. Suatu kesadaran bahwa keputusan sedang diperlukan. Kesadaran ini diikuti oleh satu periode perenungan seperti proses inkubasi.

b. Mengenali masalah. Sesudah mele- wati masa perenungan, atau karena akumulasi dari banyaknya bukti- bukti atau tanda-tanda yang tertang- kap, maka individu semakin menyadari bahwa kebutuhan untuk memutuskan sesuatu menjadi semakin nyata.

c. Menetapkan tujuan. Fase ini adalah masa mempertimbangkan harapan yang akan dicapai dalam mengambil keputusan. Tujuan pada umumnya berkaitan dengan kesenjangan antara sesuatu yang telah diobservasi dengan sesuatu yang diharapkan, berkaitan dengan permasalahan yang dihadapi. 
d. Memahami masalah. Merupakan suatu kebutuhan bagi individu untuk memahami secara benar permasalah- an, yaitu mendiagnosa akar permasa- lahan yang terjadi. Kesalahan dalam mendiagnosa dapat terjadi karena memformulasikan masalah secara salah, karena hal ini akan mempe- ngaruhi rangkaian proses selanjut- nya. Jawaban yang benar terhadap pemahaman masalah yang salah memiliki makna/akibat sama seperti halnya jawaban yang salah terhadap pemahaman masalah yang benar.

e. Menentukan Pilihan-pilihan. Jika batas-batas keputusan telah didefini- sikan dengan lebih sempit maka pilihan-pilihan dengan sendirinya lebih mudah tersedia. Namun, jika keputusan yang diambil masih didefinisikan secara luas maka proses menetapkan pilihan merupakan proses kreatif.

f. Mengevaluasi Pilihan-pilihan. Fase ini melibatkan penentuan yang lebih luas mengenai ketepatan masing- masing pilihan terhadap tujuan pengambilan keputusan.

g. Memilih. Pada fase ini salah satu dari beberapa pilihan keputusan yang tersedia telah dipilih, dengan pertimbangan apabila diterapkan akan menjanjikan suatu kepuasan.

h. Menerapkan. Fase ini melibatkan perubahan-perubahan yang terjadi karena pilihan yang telah dipilih. Efektivitas penerapan ini bergantung pada ketrampilan dan kemampuan individu dalam menjalankan tugas serta sejauh mana kesesuaian pilihan tersebut dalam penerapan.

i. Memonitor. Setelah diterapkan, maka keputusan tersebut sebaiknya dimonitor untuk melihat efektivitas dalam memecahkan masalah atau mengurangi permasalahan yang sesungguhnya

\section{PENUTUP}

Pengambilan keputusan klinis keperawatan merupakan serangkaian keputusan yang dibuat oleh perawat, dalam interaksi dengan klien mengenai pengkajian yang didapat dari klien, evaluasi data yang diamati, variasi diagnosa yang muncul serta tindakan keperawatan yang harus diambil (jan Florin. 2007, Mehee. 2014). Teori yang dikemukakan oleh Buckingham and Adams pengambilan keputusan klinis merupakan perilaku klasifikasi (Jan Florin. 2007). Klasifikasi dapat diartikan bahwa pengambilan keputusan merupakan sebuah pola tertentu sama halnya 
dengan proses keperawatan, jelas bahwa dalam setiap proses keperawatan perawat harus mampu mengambil keputusan klinis.

Penting bagi perawat untuk mampu mengambil keputusan klinis dengan melibatkan pasien dan keluarga dalam asuhan keperawatannya sehinggga proses keperawatan yang diberikan kepada klein ini diarahkan sebagai proses refleksi baik bagi perawat ataupun klien. Proses pengambilan keputusan merupakan sebuah refleksi dari perawat ataupun klien, pengambilan keputusan klinis keperawatan harus ada interaksi antara perawat-klien, pengambilan keputusan klinis keperawatan dapat dilakukan dalam setiap proses keperawatan, tugas perawat pada saat proses pengambilan keputusan ini adalah sebagai fasilitator untuk memberikan fasilitas dan dukungan pada klien,

Pengambilan keputusan yang baik dari perawat akan mendukung kualitas perawatan yang diberikan kepada pasien tetapi jika dak didukung dengan pengetahuan dan keterampilan yang baik dari perawat dalam melakukan pengambilan keputusan klinik keperawatan maka akan menurunkan mutu dan kualitas dari proses keperawatan yang diberikan kepada pasien sehingga untuk mengatasi hal tersebut peneli berpendapat perlu mengevaluasi kemampuan perawat untuk mengetahui sejauhmana pengetahuan dan keterampilan yang dimiliki perawat untuk dapat melaksanakan kerja dengan baik. Pembuatan keputusan klinik adalah hal yang sangat vital pada prakk keperawatan. Point dari pembuatan keputusan keperawatan harus memiliki dampak yang menyeluruh terhadap performa organisasi dan mampu memberikan dampak juga secara finansial. Memberikan kualitas dan pelayanan yang aman adalah tujuan dari seluruh organisasi pelayanan kesehatan. Oleh karena itu pembuatan keputusan klinik yang efekf harus benar - benar dilaksanakan (Diane L, 2018)..

\section{DAFTAR PUSTAKA}

Anwar,H. (2014). Proses Pengambilan Keputusan untuk Mengembangkan Mutu Madrasah. Jurnal Pendidikan Islam, 8(1)

Deniati,K., Anugrahwati,R.,\& Suminarti,T. (2018). PENGARUH BERFIKIR KRITIS TERHADAP KEMAMPUAN PERAWAT PELAKSANA DALAM MELAKUKAN ASUHAN 
KEPERAWATAN DI RUMAH SAKIT HERMINA BEKASI TAHUN 2016. Jurnal Kesehatan Holistik (The Journal of Holistic Healthcare), 12(1) ,21-25

Erianti,S., Machmud,R.,\& Harmawati. (2019). Determinan Pengambilan Keputusan Klinik Keperawatan di RSUD Arifin Achmad Provinsi Riau. JURNAL KESEHATAN KOMUNITAS, $5(3)$

Kusnadi,D. (2015). PENGAMBILAN KEPUTUSAN DALAM PERILAKU ORGANISASI. Jurnal Ilmiah Universitas Batanghari Jambi, 15(2)

Lutfiani D.L,Babakal,A,L,P,A. (2015).GAMBARAN TINGKAT PENGETAHUAN PERAWAT DALAM PENERAPAN STANDAR ASUAHAN KEPERAWATAN DIRUANGAN RAWAT INAP INTERNA RSUD DATOE BHINANGKANG. E-Journal Keperawatan (e-Kp)

Mugianti,S. Desember (2016). Manajemen Kepemimpinan dalam Praktek Keperawatan. Kebayoran Baru,Jakarta Selatan

Nogo,A.KINERJA PERAWAT DALAM PENERAPAN STANDAR ASUHAN KEPERAWATAN DI RUMAH SAKIT UMUM DAERAH NAIBONAT KABUPATEN KUPA. Jurnal Penelitian,18(1), 62-66

Pashar,I.,Dwiantoro,L. (2020). Pengaruh Empowerment Terhadap Pengambilan Keputusan Perawat: Kajian Literature Review. Journal of Holistic Nursing Science, 7 (2) 124-132

Purwati,E,I,I. Nuryadi, Herawati,Y,T. (2017). Pengambilan Keputusan dalam Pelaksanaan Rujukan Puskesmas sebagai Fasilitas Kesehatan Tingkat Pertama . e-Jurnal Pustaka Kesehatan, $5(2)$

Rohmah,N. (2010). INTEGRASI PROSES KEPERAWATAN DALAM PEMBELAJARAN KLINIK KEPERAWATAN ONE TO ONE TEACHING AND FEED BACK. THE INDONESIAN JOURNAL OF HEALTH SCIENCE, 1(1)

Simamora, R. H. (2019). Menjadi perawat yang: CIH'HUY. Surakarta: Kekata Publisher.

Simamora, R. H. (2005). Hubungan Persepsi Perawat Pelaksana Terhadap Penerapan Fungsi Pengorganisasian Yang Dilakukan Oleh Kepala Ruangan Dengan Kinerjanya Diruang Rawat Inap RSUD Koja Jakarta Utara (Doctoral dissertation, Tesis FIK UI, Tidak dipublikasikan). 